\title{
PERTUMBUHAN SEMAI GMELINA (Gmelina arborea Roxb.) PADA MEDIA BEKAS TAMBANG SILIKA DENGAN PENAMBAHAN PUPUK KANDANG KAMBING DAN ARANG KAYU
}

\author{
Growth for Gmelina (Gmelina arborea Roxb.) on the Post Mine Silica with the Addition of \\ Goat Manure and Wood Charcoal
}

Basuki Wasis dan Novi Anggraini

Departemen Silvikultur, Fakultas Kehutanan IPB

\begin{abstract}
Mining activity consists of land clearing, erosion of soil horizons, dredging and hoarding. The mining activities will impact to the soil fertility. The addition of soil nutrition can be done by giving goat manure and wood charcoal. This research aims to examine the effect of wood charcoal and goat manure addition to the growth of gmelina (Gmelina arborea Roxb.) seedlings on the post mine silica soil. This research used randomized complete design wit two factorials. Parameter observed in this search is high, diameter and biomass. Observations in 12 weeks whows that single treatment of wood charcoal was not significantly different to all parameters in the $95 \%$ interval. The single treatment of goat manure and its interaction with wood charcoal shows a significant different to all parameters observed. The best combination to the growth of gmelina seedling on post mine silica was $100 \mathrm{~g}$ of goat manure and $40 \mathrm{gr}$ of wood charcoal.
\end{abstract}

Key words: fertilizer of goat manure, G. arborea, wood charcoal.

\section{PENDAHULUAN}

Pertambangan merupakan salah satu sumber daya alam potensial yang dapat dimanfaatkan sebagai sumber devisa untuk pembangunan nasional karena perannya sebagai penyedia sumber daya energi yang diperlukan untuk pertumbuhan ekonomi suatu negara. Kegiatan penambangan yang umum dilakukan yaitu dengan cara pembukaan hutan, pengikisan lapisan-lapisan tanah, pengerukan, dan penimbunan. Kegiatan penambangan yang dilakukan mengakibatkan kesuburan tanah sebagai media pertumbuhan tanaman menurun.

Perkembangan industri pertambangan di Indonesia yang terus berkembang pesat harus diimbangi dengan penanganan lingkungan pasca tambang. Salah satu industri pertambangan yang berkembang adalah pertambangan silika. Silika banyak dimanfaatkan dalam berbagai aplikasi di bidang industri terutama digunakan sebagai material bangunan bahan campuran beton (Izzati et al. 2013). Kegiatan perbaikan tanah di lahan bekas tambang dapat dilakukan dengan penanaman jenis komersial dan fast growing yaitu gmelina. Menurut Sumarna (2012) gmelina juga relatif tahan dengan kondisi lahan yang kering. Pupuk kandang kambing berfungsi sebagai penambah unsur hara sehingga dapat membantu tanaman hidup di lingkungan yang kering dan miskin unsur hara. Menurut Glaser et al. (2002) dalam Ahmad (2006) pengaplikasian arang kayu pada media tumbuh dapat memperbaiki sifat kimia tanah antara lain meningkatkan kejenuhan basa, $\mathrm{pH}$ tanah, kandungan unsur hara tersedia dan menurunkan $\mathrm{Al}^{2+}$ serta $\mathrm{H}^{+}$.

\section{Tujuan}

Penelitian ini bertujuan menguji pengaruh pemberian arang kayu dan pupuk kandang kambing terhadap pertumbuhan semai gmelina pada media bekas tambang silika serta mendapatkan informasi mengenai komposisi arang kayu dan pupuk kandang kambing yang optimal bagi pertumbuhan semai gmelina pada media bekas tambang silika.

\section{METODE}

\section{Waktu dan Lokasi Penelitian}

Penelitian ini dilaksanakan di rumah kaca bagian Silvikultur dan laboratorium Pengaruh Hutan Departemen Silvikultur Fakultas Kehutanan Institut Pertanian Bogor, pada bulan Mei hingga Agustus 2014. Lokasi pengambilan media dilakukan di bekas penambangan silika Holcim. Analisis kandungan unsur hara pada media dilakukan di Laboratorium Kesuburan Tanah, Departemen Ilmu Tanah Dan Sumberdaya Lahan, Fakultas Pertanian, Institut Pertanian Bogor.

\section{Bahan dan Alat}

Alat yang digunakan dalam penelitian ini yaitu timbangan digital, caliper, polybag (ukuran $20 \mathrm{~cm} \mathrm{x}$ $20 \mathrm{~cm}$ ), alat tulis, kamera, kalkulator, alat penyiram, tallysheet, oven, software Microsoft excel, software Microsoft word, dan SPSS16.0. 
Bahan yang digunakan dalam penelitian ini yaitu semai gmelina berumur 3 bulan, media bekas tambang silika, arang kayu dan pupuk kandang kambing.

\section{Prosedur Penelitian}

Penelitian ini dilaksanakan dengan tahapan-tahapan sebagai berikut:

\section{Persiapan Media}

Media tanam yang digunakan adalah campuran dari tanah bekas tambang silika, arang kayu dan pupuk kandang kambing. Perlakuan kontrol berisi tanah bekas tambang silika $1 \mathrm{~kg}$. Perlakuan selanjutnya dilakukan penambahan pupuk kandang kambing dengan dosis sebesar $25 \mathrm{~g} /$ poybag, $50 \mathrm{~g} /$ polybag, $75 \mathrm{~g} /$ polybag, dan $100 \mathrm{~g} /$ polybag. Dosis arang kayu yang ditambahkan ke media sebesar $20 \mathrm{~g} /$ poybag, $40 \mathrm{~g} /$ polybag, $60 \mathrm{~g} /$ polybag, dan $80 \mathrm{~g} /$ polybag.

\section{Penyapihan semai}

Semai gmelina yang disapih adalah semai dengan cirri-ciri warna daun hijau, serta tidak terdapat hama dan penyakit. Jumlah semai yang digunakan yaitu 60 semai yang akan dimasukkan ke polybag yang telah terisi campuran media bekas tambang silika, arang kayu dan pupuk kandang kambing.

\section{Pemeliharaan}

Pemeliharaan yang dilakukan terhadap semai gmelina yaitu dengan penyiraman 2 kali sehari saat pagi dan sore hari.

\section{Pengambilan Data}

Pengambilan data dilakukan setiap minggu dengan parameter yang diukur yaitu tinggi dan diameter. Alat yang digunakan mengukur tinggi yaitu mistar dan untuk diameter menggunakan caliper digital. Pengukuran dilakukan sampai 12 minggu dan rekapitulasi data dicatat pada tally sheet. Pengukuran tinggi dilakukan dari pangkal batang sampai titik tumbuh pucuk semai Gmelina. Pengukuran diameter batang diukur $3 \mathrm{~cm}$ diatas pangkal batang. Data berat basah serta berat kering pucuk dan akar diambil pada saat panen. Prosedur yang dilakukan adalah bagian akar dan pucuk dipisah lalu dikeringkan di dalam oven dengan suhu $80^{\circ} \mathrm{C}$ selama 24 jam. Bagian akar dan bagian pucuk yang ditimbang sebelum di oven merupakan data berat basah pucuk dan berat basah akar, sedangkan data setelah di oven merupakan berat kering akar dan pucuk. Berat basah total dan berat kering total didapatkan dengan menjumlahkan berat akar dan berat pucuk. Analisis unsur hara dilakukan pada minggu awal dan akhir pengamatan. Sampel tanah yang diambil sebanyak dua sampel yaitu kontrol dan perlakuan yang menghasilkan pertumbuhan terbaik.

\section{Rancangan Percobaan dan Analisis Data}

Rancangan percobaan yang digunakan dalam penelitian ini yaitu rancangan acak lengkap (RAL) faktorial dengan dua faktor. Faktor pertama yaitu pupuk kandang kambing yang terdiri dari empat taraf. Faktor kedua yaitu arang kayu yang terdiri dari lima taraf.

\section{HASIL DAN PEMBAHASAN}

Tabel 1 Rekapitulasi hasil analisis sidik ragam berbagai parameter terhadap pertumbuhan semai gmelina

\begin{tabular}{lccc}
\hline & \multicolumn{3}{c}{ Perlakuan } \\
\cline { 2 - 4 } Parameter & Arang & $\begin{array}{c}\text { Pupuk } \\
\text { kandang } \\
\text { kambing }\end{array}$ & $\begin{array}{c}\text { Pupuk kandang } \\
\text { kambing*Arang }\end{array}$ \\
\hline Tinggi & $0.530 \mathrm{tn}$ & $0.000^{*}$ & $0.001^{*}$ \\
Diameter & $0.432 \mathrm{tn}$ & $0.000^{*}$ & $0.020^{*}$ \\
BBT & $0.183 \mathrm{tn}$ & $0.000^{*}$ & $0.011^{*}$ \\
BKT & $0.255 \mathrm{tn}$ & $0.001^{*}$ & $0.000^{*}$ \\
\hline
\end{tabular}

Angka-angka dalam tabel adalah nilai signifikan.

* = perlakuan berpengaruh nyata pada selang kepercayaan 95\% dengan nilai signifikan $(\operatorname{Pr}>\mathrm{F}) 0.05(\alpha)$

tn $=$ perlakuan tidak berpengaruh nyata pada selang kepercayaan 95\% dengan nilai signifikan $(\operatorname{Pr}>\mathrm{F}) 0.05(\alpha)$

Parameter yang diamati dalam penelitian ini yaitu tinggi, diameter, berat basah total (BBT), dan berat kering total (BKT) dari semai gmelina. Pengamatan yang dilakukan selama 12 minggu menunjukkan bahwa pemberian arang kayu secara tunggal tidak berpengaruh nyata terhadap semua parameter yang diamati pada selang kepercayaan 95\%. Pemberian pupuk kandang kambing secara tunggal dan interaksi dengan arang kayu berpengaruh nyata pada semua parameter yang diamati (Tabel 1).

Hasil sidik ragam (Tabel 1) menunjukkan interaksi pemberian pupuk kandang kambing dan arang kayu berpengaruh nyata terhadap parameter pertumbuhan tinggi dan diameter. Hasil uji lanjut duncan (Tabel 2 dan Tabel 3) menunjukkan pemberian pupuk kandang kambing dengan dosis 100 gr dan arang 40 gr (A5B3) memberikan hasil terbaik dibandingkan interaksi lainnya. Hasil pertumbuhan tinggi dan diameter dari uji duncan juga menunjukkan perlakuan A5B3 tidak berbeda nyata dengan perlakuan A5B1 (pupuk kandang kambing 100 gr + arang kayu 0 gr), A5B2 (pupuk kandang kambing 100 gr + arang kayu 20 gr) dan perlakuan A4B3 (pupuk kandang kambing 75 gr + arang kayu 40 gr).

Kondisi media bekas tambang pada umumnya adalah miskin hara (marjinal). Perbedaan pengaruh penambahan pupuk kandang kambing dan arang kayu pada masing-masing dosis yang diberikan dipengaruhi oleh kandungan hara pada media bekas tambang silika. Oleh karena itu, penambahan pupuk kandang dan arang kayu bergantung pada kebutuhan dan tanaman dalam menyerap unsur hara (Wasis dan Fathia 2011).

Pertumbuhan merupakan meningkatnya jumlah sel dan ukuran sel. Pertumbuhan juga dapat diartikan sebagai peningkatan bahan kering, tinggi, volume, dan luas daun (Gardner et al. 1985 dalam Nugroho 2013). Pertumbuhan tanaman sangat dipengaruhi oleh ketersediaan unsur hara di dalam tanah yang dapat diserap oleh tanaman. Kandungan hara dalam pupuk organik bervariasi bergantung pada bahan organik yang terkandung dalam pupuk, tingkat kematangan pupuk 
dan cara penangannnya. Menurut Tisdale et al. (1985) dalam Aminah (2003) kandungan unsur hara dalam pupuk kandang kambing yaitu $\mathrm{H}_{2} \mathrm{O}(60 \%), \mathrm{N}(0.75 \%)$, $\mathrm{P}_{2} \mathrm{O}_{5}(0.50 \%)$, dan $\mathrm{K}_{2} \mathrm{O}(0.45 \%)$.

Tabel 2 Hasil uji duncan pengaruh interaksi pupuk kandang kambing dan arang kayu terhadap pertumbuhan tinggi semai gmelina

\begin{tabular}{ccc}
\hline Perlakan & $\begin{array}{c}\text { Rata-rata pertumbuhan } \\
\text { tinggi }(\mathrm{cm})\end{array}$ & $\begin{array}{c}\text { \% peningkatan } \\
\text { terhadap kontrol }\end{array}$ \\
\hline A1B1 & $4.1667 \mathrm{f}$ & 0.00 \\
A1B2 & $7.6333 \mathrm{ef}$ & 83.20 \\
A1B3 & $14.1333 \mathrm{bcdef}$ & 239.20 \\
A1B4 & 21.5000 abcde & 416.00 \\
A2B1 & $9.2667 \mathrm{cdef}$ & 122.40 \\
A2B2 & $5.6000 \mathrm{ef}$ & 34.40 \\
A2B3 & $15.9333 \mathrm{bcdef}$ & 282.40 \\
A2B4 & $1.1333 \mathrm{cdef}$ & 167.20 \\
A3B1 & 9.0000 def & 116.00 \\
A3B2 & 24.5333 abcd & 488.80 \\
A3B3 & $16.1333 \mathrm{bcdef}$ & 287.20 \\
A3B4 & $25.6667 \mathrm{abcd}$ & 516.00 \\
A4B1 & $19.7333 \mathrm{bcdef}$ & 373.60 \\
A4B2 & $15.0667 \mathrm{bcdef}$ & 261.60 \\
A4B3 & $28.0667 \mathrm{ab}$ & 573.60 \\
A4B4 & $19.0667 \mathrm{bcdef}$ & 357.60 \\
A5B1 & $28.9333 \mathrm{ab}$ & 594.40 \\
A5B2 & $28.2000 \mathrm{ab}$ & 576.80 \\
A5B3 & $36.2667 \mathrm{a}$ & 770.40 \\
A5B4 & $25.9667 \mathrm{abcd}$ & 523.20 \\
\hline
\end{tabular}

Penambahan pupuk kandang dapat memperbaiki sifat fisik dan kimia tanah. Sifat fisik dari tanah yang dapat diperbaiki yaitu permeabilitas, porositas, struktur, kation dan daya pegang air tanah (Hardjowigeno 2007). Jumlah bahan organik yang ada akan menentukan kemampuan media dalam menahan dan menyimpan air (Nugroho 2013). Keuntungan yang akan diperoleh dengan pemberian arang kayu menurut Gusmailina et al. (2000) antara lain dapat memperbaiki sirkulasi air dan udara yang ada di dalam tanah. Sirkulasi air dan udara dalam tanah yang cukup dapat membantu akar untuk berkembang lebih baik sehingga tanaman dapat tumbuh lebih subur. Selain itu arang kayu dapat meningkatkan $\mathrm{pH}$ tanah serta dapat berfungsi sebagai media untuk mengikat karbon dalam tanah.

Tabel 3 Hasil uji duncan pengaruh interaksi pupuk kandang kambing dan arang kayu terhadap pertumbuhan diameter semai gmelina

\begin{tabular}{ccc}
\hline Perlakuan & $\begin{array}{c}\text { Rata-rata pertumbuhan } \\
\text { diameter }(\mathrm{mm})\end{array}$ & $\begin{array}{c}\text { \% peningkatan } \\
\text { terhadap kontrol }\end{array}$ \\
\hline A1B1 & $1.1000 \mathrm{~cd}$ & 0.00 \\
A1B2 & $0.7733 \mathrm{~d}$ & -29.70 \\
A1B3 & $1.5533 \mathrm{abcd}$ & 41.21 \\
A1B4 & $1.5900 \mathrm{abcd}$ & 44.55 \\
A2B1 & $1.0900 \mathrm{~cd}$ & -0.91 \\
A2B2 & $1.1133 \mathrm{abcd}$ & 1.21 \\
A2B3 & $1.4933 \mathrm{abcd}$ & 35.76 \\
A2B4 & $1.4600 \mathrm{bcd}$ & 32.73 \\
A3B1 & $7.2400 \mathrm{cdef}$ & 81.82 \\
A3B2 & $2.0000 \mathrm{abcd}$ & 80.61 \\
A3B3 & $1.8300 \mathrm{abcd}$ & 66.36 \\
A3B4 & $1.7367 \mathrm{abcd}$ & 57.88 \\
\hline
\end{tabular}

\begin{tabular}{ccc}
\hline Perlakuan & $\begin{array}{c}\text { Rata-rata pertumbuhan } \\
\text { diameter }(\mathrm{mm})\end{array}$ & $\begin{array}{c}\text { \% peningkatan } \\
\text { terhadap kontrol }\end{array}$ \\
\hline A4B1 & $2.0100 \mathrm{abcd}$ & 82.73 \\
A4B2 & $1.3333 \mathrm{~cd}$ & 21.21 \\
A4B3 & $1.9867 \mathrm{abcd}$ & 80.61 \\
A4B4 & $1.9700 \mathrm{abcd}$ & 79.09 \\
A5B1 & $2.2733 \mathrm{abc}$ & 106.67 \\
A5B2 & $2.6833 \mathrm{ab}$ & 143.94 \\
A5B3 & $2.7767 \mathrm{a}$ & 152.42 \\
A5B4 & $2.6800 \mathrm{ab}$ & 143.64 \\
\hline
\end{tabular}

Pertumbuhan diameter juga dipengaruhi oleh pertumbuhan akar yang efektif (Daniel et al. 1987 dalam Nurliawati 2006). Pertumbuhan akar sangat dipengaruhi oleh struktur tanah. Penambahan pupuk kandang dan arang kayu dapat membantu pertumbuhan tanaman karena struktur tanah sebagai media tumbuh dapat diperbaiki. Penggunaan arang kayu juga dapat merangsang pertumbuhan tanaman karena berperan dalam konservasi lingkungan sebagai kondisioner tanah (Siregar 2005).

\section{Berat Basah Total dan Berat Kering total}

Tabel 4 Hasil uji duncan pengaruh interaksi pemberian pupuk kandang kambing dan arang kayu terhadap berat basah total semai gmelina

\begin{tabular}{|c|c|c|}
\hline Perlakuan & $\begin{array}{l}\text { Rata-rata berat basah } \\
\text { total (gr) }\end{array}$ & $\begin{array}{l}\text { \% peningkatan } \\
\text { terhadap kontrol }\end{array}$ \\
\hline A1B1 & $3.0633 \mathrm{f}$ & 0.00 \\
\hline $\mathrm{A} 1 \mathrm{~B} 2$ & $6.8533 \mathrm{def}$ & 123.72 \\
\hline A1B3 & $5.6900 \mathrm{ef}$ & 85.75 \\
\hline A1B4 & 9.5833 bcdef & 212.84 \\
\hline $\mathrm{A} 2 \mathrm{~B} 1$ & 10.7533 bcdef & 251.03 \\
\hline $\mathrm{A} 2 \mathrm{~B} 2$ & 7.4067 cdef & 141.78 \\
\hline A2B3 & 5.5067 ef & 79.76 \\
\hline A2B 4 & 7.4833 bcdef & 144.29 \\
\hline A3B1 & 7.2400 cdef & 136.34 \\
\hline A3B2 & 10.6900 bcdef & 248.97 \\
\hline A3B3 & $7.2500 \mathrm{cdef}$ & 136.67 \\
\hline A3B4 & $15.6033 \mathrm{bc}$ & 409.36 \\
\hline A4B1 & 8.0300 bcdef & 162.13 \\
\hline $\mathrm{A} 4 \mathrm{~B} 2$ & $15.6300 \mathrm{bc}$ & 410.23 \\
\hline A4B3 & $14.4933 \mathrm{bcd}$ & 373.12 \\
\hline A4B4 & 13.7067 bcde & 347.44 \\
\hline A5B1 & $12.3033 \mathrm{bcde}$ & 301.63 \\
\hline A5B2 & $16.1233 \mathrm{~b}$ & 426.33 \\
\hline A5B3 & $23.7400 \mathrm{a}$ & 674.97 \\
\hline A5B4 & 8.9133 bcdef & 190.97 \\
\hline
\end{tabular}

Hasil sidik ragam (Tabel 1) menunjukkan interaksi pemberian pupuk kandang kambing dan arang kayu berpengaruh nyata terhadap berat basah total dan berat kering total. Uji Duncan (Tabel 4 dan Tabel 5) menunjukkan perlakuan A5B3 memberikan hasil berat basah total dan berat kering total tertinggi diantara perlakuan lainnya.

Berat basah merupakan pertambahan massa pada tanaman yang diukur dengan cara memanen seluruh tanaman atau bagian tanaman yang diinginkan dan menimbangnya dengan segera agar air yang dikandung tanaman tidak banyak yang menguap. Berat kering tanaman menggambarkan biomassa sebagai hasil dari metabolisme dalam keadaan tanpa kadar air. Berat 
kering total menggambarkan kemampuan tanaman dalam mengambil unsur hara dari media tanam untuk menunjang pertumbuhannya (Karepesina 2007). Semakin tinggi nilai BKT yang didapatkan semakin tinggi menggambarkan kualitas pertumbuhan semai semakin baik (Putri et al. 2010).

Tabel 5 Hasil uji duncan pengaruh interaksi pemberian pupuk kandang kambing dan arang kayu terhadap berat kering total semai gmelina

\begin{tabular}{ccc}
\hline Perlakuan & $\begin{array}{c}\text { Rata-rata berat kering } \\
\text { total (gr) }\end{array}$ & $\begin{array}{c}\text { \% peningkatan } \\
\text { terhadap kontrol }\end{array}$ \\
\hline A1B1 & $1.4200 \mathrm{e}$ & 0.00 \\
A1B2 & $2.6000 \mathrm{de}$ & 83.10 \\
A1B3 & 3.0766 bcd & 116.67 \\
A1B4 & 5.2733 abcde & 271.36 \\
A2B1 & 3.9200 bcde & 176.06 \\
A2B2 & 3.0666 cde & 115.96 \\
A2B3 & $2.9500 \mathrm{cde}$ & 107.75 \\
A2B4 & 3.2200 cde & 126.76 \\
A3B1 & 3.6933 cdef & 160.09 \\
A3B2 & 3.8600 bcde & 171.83 \\
A3B3 & 3.3800 bcde & 138.03 \\
A3B4 & 6.5100 abcd & 358.45 \\
A4B1 & 4.2400 bcde & 198.59 \\
A4B2 & 3.6633 bcde & 157.98 \\
A4B3 & 7.0100 bcd & 393.66 \\
A4B4 & 6.5233 abcd & 359.39 \\
A5B1 & 6.2033 abcd & 336.85 \\
A5B2 & 7.6033 ab & 435.45 \\
A5B3 & 9.1700 a & 545.77 \\
A5B4 & 4.4233 bcde & 211.50 \\
\hline
\end{tabular}

\section{Analisis Unsur Hara Tanah}

Analisis unsur hara tanah dilakukan 2 kali yaitu sebelum penelitian dan setelah penelitian. Hasil analisis tanah menunjukkan bahwa pemberian pupuk kandang dan arang dapat meningkatkan $\mathrm{pH}$ dan menurunkan zat beracun yang dikandung oleh tanah bekas tambang silika (Tabel 6).

Peningkatan $\mathrm{pH}$ tanah dari analisis awal yaitu 2.4 menjadi 3.7 setelah diberi penambahan kandang 100 gr dan arang 40 gr. Kandungan unsur hara makro primer seperti N, P, K juga mengalami peningkatan. Peningkatan unsur hara makro sekunder yaitu $\mathrm{Ca}$ dan $\mathrm{Mg}$ mengalami peningkatan menjadi 10.03 (me/100gram) dan 4.66 (me/100gram). Pupuk kandang dapat meningkatkan kandungan bahan organik yang berperan pada siklus hara dalam tanah (Suwahyono 2011). Bahan organik berperan secara kimia diantaranya sebagai sumber unsur hara N, dan $\mathrm{P}$.

Kandungan logam beracun yang terdapat di tanah bekas tambang yaitu Al mengalami penurunan sangat drastis menjadi hampir tidak bisa terbaca pada saat analisis kedua dilakukan. Arang kayu dapat berfungsi sebagai perangsang pertumbuhan tanaman dan menyerap zat-zat racun yang terkandung di dalam tanah (Istantini 2012). Arang kayu juga memiliki pH yang bersifat alkalis dan sebagai penyerap dan pelepas unsur hara karena memiliki permukaan yang besar, relatif sama dengan koloid tanah. Nilai pH tanah menunjukkan reaksi sifat kemasaman atau alkalinitas tanah dan banyaknya konsentrasi ion hidrogen $\left(\mathrm{H}^{+}\right)$di dalam tanah. Nilai pH juga dapat menunjukkan kemungkinan adanya unsur beracun dalam tanah.

Tabel 6 Hasil analisis kimia tanah

\begin{tabular}{|c|c|c|}
\hline $\begin{array}{l}\text { Sifat kimia } \\
\text { tanah }\end{array}$ & $\begin{array}{l}\text { Tanah bekas } \\
\text { tambang } \\
\text { silika } \\
\text { (A1B1) }\end{array}$ & $\begin{array}{l}\text { Tanah bekas } \\
\text { tambang silika }+ \\
\text { pupuk } 100 \mathrm{gr}+ \\
\text { arang } 40 \mathrm{gr} \\
(\mathrm{A} 5 \mathrm{~B} 3)\end{array}$ \\
\hline $\mathrm{pH} \mathrm{H}{ }_{2} \mathrm{O}$ & 2.40 & 3.70 \\
\hline N-tot $(\%)$ & 0.19 & 0.21 \\
\hline $\mathrm{P}$ ters $(\mathrm{ppm})$ & 7.80 & 20.80 \\
\hline $\mathrm{Ca}$ (me/100gram) & 2.27 & 10.03 \\
\hline Mg (me/100gram) & 0.45 & 4.66 \\
\hline $\mathrm{K}$ (me/100gram) & 0.18 & 0.49 \\
\hline $\mathrm{Na}$ (me/100gram) & 0.54 & 0.65 \\
\hline $\mathrm{Al}$ (me/100gram) & 6.12 & - \\
\hline H (me/100gram) & 0.68 & 0.68 \\
\hline $\mathrm{Fe}(\mathrm{ppm})$ & 87.78 & 42.12 \\
\hline $\mathrm{Cu}(\mathrm{ppm})$ & 15.00 & 2.78 \\
\hline $\mathrm{Zn}(\mathrm{ppm})$ & 3.49 & 6.76 \\
\hline Mn (ppm) & 44.95 & 31.41 \\
\hline $\mathrm{KB}(\%)$ & 30.00 & 66.10 \\
\hline
\end{tabular}

Nitrogen (N) yang ada di dalam tanaman mempunyai fungsi sebagai komponen utama protein, hormon, vitamin, klorofil, dan enzim-enzim esensial yang dibutuhkan untuk pertumbuhan tanaman (Munawar 2011). Gejala kekurangan N pada umumnya dapat dilihat dari daun yang kuning dan gugur. Gejala lain yang timbul yaitu pertumbuhan tanaman kerdil dan pertumbuhan akar terbatas. Kelebihan $\mathrm{N}$ pada tanaman dapat menyebabkan batang lemah dan mudah roboh, daya tahan tanaman terhadap penyakit berkurang dan kematangan tanaman berjalan lambat (Hardjowigeno 2007).

Fosfor $(\mathrm{P})$ yang tersedia di dalam tanah sebagian besar terdapat dalam bentuk yang tidak tersedia bagi tanaman (Usman 1980). Unsur P digunakan tanaman untuk merangsang pertumbuhan akar, memperkuat batang tanaman, membantu asimilasi dan respirasi, serta merupakan bahan dasar protein. Gejala kekurangan unsur $\mathrm{P}$ antara lain tanaman menjadi kerdil dan daun berubah warna menjadi ungu atau coklat. Gejala ini akan terlihat jelas pada tanaman yang masih muda (Hardjowigeno 2003).

Kalium (K) di dalam tanah merupakan $\mathrm{K}$ inorganik (mineral). Unsur $\mathrm{K}$ digunakan dalam fotosintesis karena terlibat didalam sintesis ATP, produksi aktivitas enzimenzim fotosintesis dan penyerapan $\mathrm{CO}_{2}$ melalui mulut daun. Unsur $\mathrm{K}$ juga terlibat dalam proses pemasakan buah. Unsur $\mathrm{K}$ pada tanaman buah-buahan dapat memperbaiki ukuran, warna, rasa, dan kulit buah (Munawar 2011).

KB (kation basa) menunjukkan perbandingan jumlah kation basa dan kation asam. Kation basa pada umumnya merupakan unsur hara yang diperlukan tanaman yaitu $\mathrm{Ca}^{++}, \mathrm{Mg}^{++}, \mathrm{K}^{+}$, dan $\mathrm{Na}^{+}$. Hubungan $\mathrm{KB}$ dan $\mathrm{pH}$ berkorelasi positif. Jika $\mathrm{pH}$ tinggi maka $\mathrm{KB}$ dalam tanah akan tinggi pula (Hardjowigeno 2007). Hasil analisis kimia tanah menunjukkan perubahan $\mathrm{pH}$ dan KB berkorelasi positif yaitu pada perlakuan A5B3 
terjadi kenaikan $\mathrm{pH}$ dan $\mathrm{KB}$ menjadi 3.7 dan $66.1 \%$ dari sebelumnya 2.4 dan $30 \%$.

\section{SIMPULAN DAN SARAN}

\section{Simpulan}

Penambahan pupuk kandang kambing dan arang kayu pada media bekas tambang silika berpengaruh nyata pada semua parameter pengamatan yaitu tinggi, diameter, berat basah total dan berat kering total. Penambahan pupuk kandang kambing dan arang kayu tidak dapat dilakukan secara tunggal untuk memperoleh hasil pertumbuhan yang optimal. Kombinasi dosis penambahan terbaik bagi pertumbuhan semai gmelina pada media bekas tambang silika, yaitu kombinasi $100 \mathrm{~g}$ pupuk kandang kambing dan $40 \mathrm{~g}$ arang kayu.

\section{Saran}

Dosis pupuk kandang kambing dan arang kayu yang optimal dapat digunakan untuk membantu revegetasi di lahan bekas tambang HEF. Perlu penelitian lebih lanjut untuk mengetahui pengaruh perlakuan terhadap semai yang ditanam di lapang (lahan bekas tambang silika).

\section{DAFTAR PUSTAKA}

Aminah. 2003. Pengaruh frekuensi penyiraman dan dosis pupuk kandang terhadap pertubuhan dan hasil lidah buaya (Aloe chiensis Baker) [tesis]. Bogor (ID): Institut Pertanian Bogor.

Djatmiko et al. 1985. Pengolahan Arang dan Kegunaan-nya. Bogor (ID): Agro Industri Press.

Gusmailina et al. 2000. Alternatif arang aktif sebagai soil conditioning pada tanaman. Buletin Penelitian Hasil Hutan. 19(3):185-199.
Hardjowigeno. 2007. Ilmu tanah. Jakarta (ID) : Akademika Pressindo.

Istantini A. 2012. Aplikasi arang tempurung kelapa dan kotoran sapi (bokashi) terhadap pertumbuhan semai jabon pada media tanam tailing tambang emas [skripsi]. Bogor (ID): Fakultas Kehutanan, Institut Pertanian Bogor.

Izzati et al. 2013. Sintesis dan karakterisasi kekristalan nanosilika berbasir pasir bancar. Jurnal Inovasi Fisika Indonesia. 2(3):19-22.

Karepesina S. 2007. Keanekaraman fungi mikoriza arbuskla dari bawah tegakan jati ambon (Tectona grandis Linn. F.) dan potensi pemanfaatannya [tesis]. Bogor (ID): Institut Pertanian Bogor.

Munawar A. 2011. Kesuburan Tanah dan Nutrisi Tanaman. Bogor (ID): IPB press.

Nugroho AW. 2013. Pengaruh komposisi medi tanam terhadap pertumbuhan awal cemara udang (Casuarina equisetifois var. Incana) pada gumuk pasir pantai. Indonesia Forest Rehabilitation Journal. 1(1):113-125.

Siregar CA. 2005. Pemanfaatan arang untuk memperbaiki kesuburan tanah dan pertumbuhan Acacia mangium. Prosiding Ekspose Hasil Litbang Hutan dan Konservasi Alam. Hal: 15-23.

Soemeinaboedhy IN, Tejowulan RS. 2007. Pemanfaatan berbagai macam arang sebagai sumber unsur hara $\mathrm{P}$ dan $\mathrm{K}$ serta sebagai pembenah tanah. Agroteksos. 17:114-122.

Suwahyono U. 2011. Petunjuk Praktis Penggunaan Pupuk Organik secara Efektif dan Efisien. Jakarta (ID): Penebar Swadaya.

Wasis B, Fathia N. 2011. Pengaruh pupuk NPK terhadap pertumbuhan semai gmelina (Gmelina arborea Roxb.) pada media tanah bekas tambang emas (tailing). Jurnal Silvikultur Tropika. 2(1):14-18.

Usman R. 1980. Pengantar Mirobiologi Tanah. Bandung (ID): FMIPA Unpad. 